\title{
The Employment Ecosystem of Bizkaia as an Emerging Common in the Face of the Impact of COVID-19
}

\author{
Ekhi Atutxa $^{1, *(\mathbb{D})}$, Iñigo Calvo-Sotomayor ${ }^{2}$ (D) and Teresa Laespada ${ }^{3}$ \\ 1 Department of Finance and Economics, University of Deusto, 48007 Bilbao, Spain \\ 2 Department of Management, University of Deusto, 48007 Bilbao, Spain; inigo.calvo@deusto.es \\ 3 Department of Social Psychology, University of Deusto, 48007 Bilbao, Spain; laespada@deusto.es \\ * Correspondence: ekhi.atutxa@deusto.es
}

Citation: Atutxa, Ekhi, Iñigo Calvo-Sotomayor, and Teresa Laespada. 2021. The Employment Ecosystem of Bizkaia as an Emerging Common in the Face of the Impact of COVID-19. Social Sciences 10: 407. https://doi.org/10.3390/socsci10110407

Academic Editor: Juan Carlos Martin Hernandez

Received: 1 October 2021

Accepted: 16 October 2021

Published: 21 October 2021

Publisher's Note: MDPI stays neutral with regard to jurisdictional claims in published maps and institutional affiliations.

Copyright: (c) 2021 by the authors. Licensee MDPI, Basel, Switzerland. This article is an open access article distributed under the terms and conditions of the Creative Commons Attribution (CC BY) license (https:// creativecommons.org/licenses/by/ $4.0 /)$.

\begin{abstract}
In the context of the impact of COVID-19 pandemic in Bizkaia (Basque Country, Spain), and from the renewed Commons paradigm, this research analyzes the initial response given by the region's employment ecosystem. Based on extensive quantitative and qualitative methods, it empirically explores the catalytic role that local public and social entities could play in coordinating an organized and systemic response of the employment-related stakeholders to an external impact, such as the current pandemic. The study of databases specifically provided by the Public Administrations for this research, in combination with two survey processes conducted to the main agents of the ecosystem, led to a greater understanding of the benefits of an organized and systemic reaction. From the community identification of a priori unrecognized impacts by individual actors to the proposal of actions closely connected to their short and long-term needs, the article finally presents recommendations aimed at strengthening the resilience and collaboration of the collective action.
\end{abstract}

Keywords: ecosystem; employment; commons; region; COVID-19; Bizkaia

\section{Introduction}

The global impact of COVID-19 appears to place countries, territories, and local communities in front of a great threat. After leaving behind the 2008 Great Recession, COVID-19 is once again pummeling a precarious labor market and global economic system (Boutiller and Castilla-Ramos 2012; International Labour Office 2011; OIT Americas 2020). Emerging epidemics, large-scale cyberattacks, financial crises, or climate change have turned into endemic systemic risks (Rasul 2020; Goldin and Mariathasan 2014; Goldin and Muggah 2020; Smith et al. 2014). Society is not going through individual, isolated crises, "but rather a crisis bundle, the sum of crises so intimately intertwined with each other that we are unable to distinguish the causes and effects" (Ramonet 2011). These crises rock each individual from every community, becoming a "global player" (Beck 2006) whereby each individual's most intimate and local facets are governed by global logics (Wieviorka 2020).

The impossibility of having a complete and comprehensive vision of local phenomena that quickly ascend to a global level means that unforeseen events cause major interruptions that cannot be detected in advance. This is the case to such an extent that it is increasingly complex to decide whether they are surprising incidents, known as Black Swans (Taleb 2007), or previously detected events—so-called "Gray Rhinos" (Wucker 2016) -that humans are incapable of managing pre-emptively. However, we could point to what Marcel Mauss called a "total social fact", since this affects all aspects of community life (healthcare, culture, society, politics, economy, etc.) (Wieviorka 2020).

It seems likely that the planet's small territories and communities will sustain external shocks of varying intensity and impact. The increased appearance of infectious diseases with a global impact, for example, points in this direction Smith et al. 2014). We are facing scenarios with an ever-increasing degree of uncertainty, meaning that local communi- 
ties and territories, and their ability to overcome traumatic circumstances, are becoming essential aspects of management.

In this context, local employment ecosystems, considered following the renewed paradigm of the Commons (Calle et al. 2017; Bollier and Helfrich 2014; Byrne and Glover 2002; Ostrom 2015), have been transformed into spaces of opportunity for collective collaboration able to equip territories with increased reliability and adaptability (common forms of government). What we in this investigation have termed Employment Commons, meaning employment ecosystems based on reciprocity and cooperative forms of governance, allow for the creation of living machines (Morin 2008, p. 17): local economic and social systems that are much more resilient and adaptable to the impacts of growing risks and crises. Employment Commons could make it possible for territories and communities to develop an increased capacity to withstand external shocks, since the occupancy dimension in a specific environment is shaped as an element of strength, meaning the ability to make adjustments for specific professional profile labor supply and demand.

As such, these employment area Commons take on distinctive features. In order to achieve greater resilience, of particular interest are (1) the search for a human scale for social and economic activity, and placing people at the center (Max-Neef 1993); (2) care for a diverse socio-economic ecosystem; (3) recognition and inclusion of the most vulnerable groups (Pickett and Wilkinson 2010); (4) endogenous, sustainable development through the strengthening of the territory's capacities (Vázquez 2007); and (5) the promotion of values such as the defense of diversity and competence (Riechman 2004), among other aspects. Therefore, in line with recent scientific publications (Calle et al. 2017; Laclau and Mouffe 2014), we would not only be facing a conception of the Commons as a complement to the traditional public-state and private-market spheres of governance. The Commons would be thought from its capacity to critically review this conventional representation of the economy and to propose alternative and democratic forms of self-government capable of placing collective (and not only individual) well-being at the center of human action. Thus, beyond liberal democracy, decision-making and participation would be subsumed to continuous, reflexive, unfinished, and inclusive collective processes (Lucarelli and Vercellone 2014; Vercellone and Giuliani 2019).

Promoting and implementing these aspects requires collective, concerted action from the stakeholders that make up employment ecosystems: companies, associations, the general public, professional training centers, universities, technology centers, etc. The coordination of this collective action is one where the stakeholders, local public administrations, can play a singular role (Dahlberg and Siapera 2007).

As we put forth in this paper, local public administrations such as Bizkaia Provincial Council could act as an agent of change in the coordination of a joint, organized employment ecosystem response to impacts like those of COVID-19. Understanding the employment ecosystem as a Commons could provide them with greater collective coordination capacity. In fact, when faced with the growing and exponential complexity caused by globalization, local public administrations can equip Employment Commons with the balancing mechanisms necessary to mitigate and adapt to these shocks. In addition, as this study concludes, they could also facilitate management and a reduction of said complexity as part of the employment ecosystem's own strategies.

Specifically, the research problem that this article addresses is how a local employment ecosystem that is progressively supported by cooperative and participatory forms of governance-meaning an emerging Employment Common-analyzes and responds to the external shock of the COVID-19 pandemic. The ecosystem analyzed is located in Bizkaia, an area in Northern Spain that is one of the Basque Autonomous Community's three territories. The main public institution in this small territory is the Bizkaia Provincial Council, which has extensive powers and even its own treasury and regulatory, tax collection, and fiscal management abilities.

As the Provincial Council is the main local public institution to be part of Bizkaia's employment ecosystem, the main contribution of this research is to analyze and characterize 
its role in the participatory and cooperative alignment of assessments, needs, and responses thereto when faced with external shocks. Specifically, analysis is focused on the collective definition and implementation of this public institution's employment promotion and defense policies rolled out through its Department of Employment, Social Inclusion and Equality in order to provide an initial response to the pandemic's impact. Among other topics, it shows the importance of versatility when it comes to implementing measures (above all through dynamic balanced budgets), the necessary participation and cooperation of the rest of the ecosystem's stakeholders, response speed and flexibility and, lastly, the importance of having an economy geared towards the mission, which means evolving and changing tools, responses, and government culture (Mazzucato 2021).

The analysis highlights how Bizkaia Provincial Council is the backbone of its territory's employment ecosystem, and the importance of local-level public action so that an embryonic Employment Common is able to face high-impact shocks. As an integral part of this Employment Common being created, and through the recognition and defense of the other collective subjects that make up employment ecosystems, this research demonstrates the importance of local public institutions when it comes to safeguarding and upholding common goods such as "employment".

The paper is structured as follows: after the introduction section, in Section 2 the materials and methods are presented; in Section 3, the emerging employment commons in Bizkaia is analyzed. In the final section, main ideas are discussed in relation to the regional employment ecosystem as a common.

\section{Materials and Methods}

Through the renewed paradigm of the commons, the research shows how, in 2020, Bizkaia Provincial Council catalyzed an appropriate collective response through economic policy focused on labor to face the external impact. This response consisted of two fundamental phases. First was carrying out an ecosystemic assessment of the territory's employment situation through an inclusive and participatory process to later define and implement dynamic labor policies to face COVID-19.

As such, through the application of methodological triangulation (Carter et al. 2014; Rothbauer 2008; Bogdan and Biklen 2006) (Figure 1), the research is focused on a case study of the role played by local public administration in improving an employment ecosystem's resilience. Specifically studied are the emerging Employment Common's response to the pandemic's impact in Bizkaia (Basque Country), and the role of local public administrations (Bizkaia Provincial Council) when it comes to coordinating a collective response.

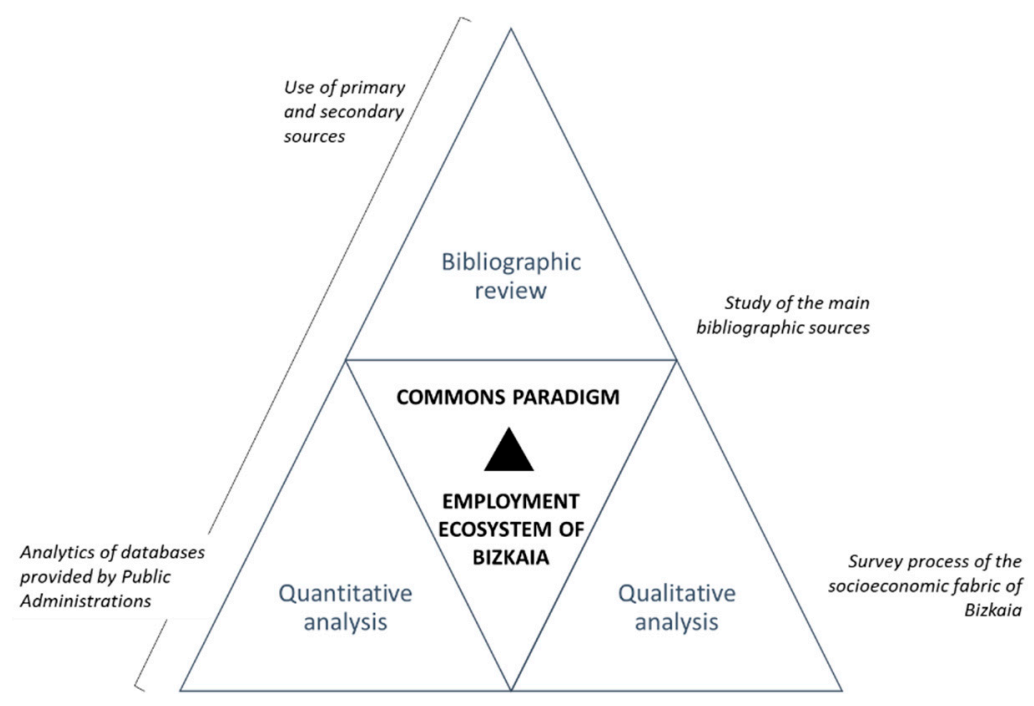

Figure 1. Representation of the Methodological Triangulation method. 
The analysis and study of diverse sources of secondary information (Eustat, Basque Government, Spanish National Statistics Institute-INE), and consulting and collecting primary sources citing the considerations of the entities affected by the crisis' impact are at the heart of this research article. The assessment and analysis carried out are the result of various social science methodologies being applied. In addition to a bibliographical review to characterize the employment ecosystem in Bizkaia from the perspective of the Commons (Calle et al. 2017; Bollier and Helfrich 2014; Byrne and Glover 2002; Ostrom 2015), the application of quantitative analyses from different perspectives and their combination with qualitative approaches have fostered a solid and rigorous assessment of the impact that COVID-19 produced in said ecosystem, as well as the role of Bizkaia Provincial Council-the main regional public institution and part of the employment ecosystem — to align the territory's assessment, needs, and responses to external shocks.

Quantitative analyses have been focused on the study of databases provided by the Public Administrations in their various scales, from national (Spanish National Statistics Institute-INE) and regional (Eustat) statistics institutes, to data that the Spanish and Basque Governments have been collecting on measures they have gone about implementing during the first months of the crisis. Specifically, access was granted and analysis was carried out on the implementation of ERTEs (temporary lay-off schemes) and their initial consequences for the employment ecosystem in Bizkaia, as well as COVID-19's impact on employment.

In terms of qualitative analysis, stakeholders to consult were identified through Snowball Sampling (Browne 2005) and Purposive Sampling (Patton 2002), both non-probabilistic methods that were singularly appropriate for this investigation's in-depth understanding of the Bizkaia employment ecosystem's impacts and needs. In the exhaustive fieldwork where various information-rich stakeholders were analyzed (Bryman and Bell 2007), empirical saturation shaped the sample size (Guest et al. 2006; Morse 1994).

During the second fortnight of the month of April 2020, Bizkaia Provincial Council carried out a survey process on 81 relevant socio-economic entities (Appendix A) that make up Bizkaia's employment ecosystem (Figure 2). List of Surveyed Entities. Fifty-six responses were received, which represents $70 \%$ of the total sample, comprised of city councils, local development, and employment centers, the third sector, vocational training centers, universities, and business associations. The complete list of entities that responded can be consulted in this article's Annexes. To complement this work, a second survey process was launched at the end of April 2020 with more than 50 companies and entities connected to Bizkaia's productive fabric, of which 30 answered ( $60 \%$ response rate).

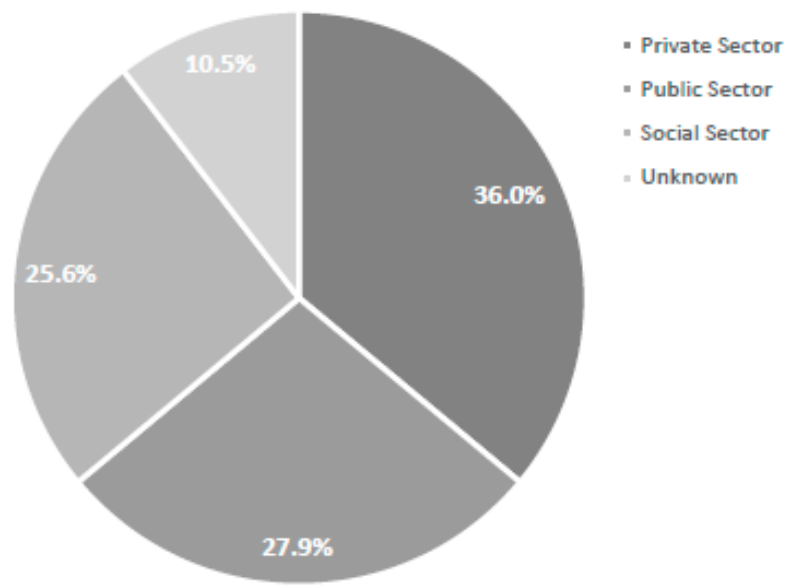

(a)

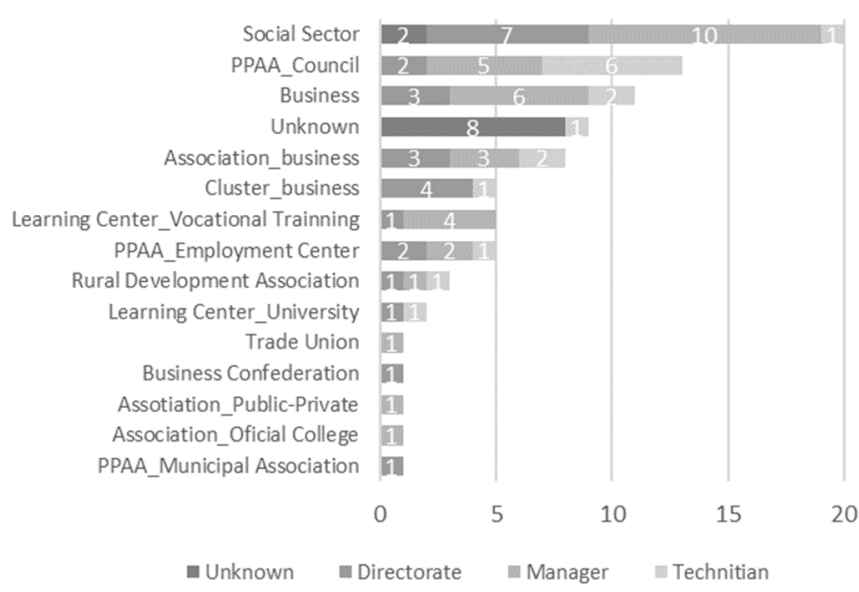

(b)

Figure 2. Survey process sample (a) distribution of the responses received according to the typology of the entity; (b) distribution of the responses received according to the position of the respondent. 
These two survey processes achieved a balanced and significant representation of activities in the three sectors (public, private, and social). Among others, 20 social entities and 1 trade union, 11 city councils, 13 clusters and business associations, 11 companies and 1 business confederation, 5 local development and employment centers, 3 rural development associations, and 2 universities and 5 professional training centers in Bizkaia participated in the process, once again showing their high level of commitment to the territory's positive development. Of the individuals that responded, $69.7 \%$ are entity directors or department managers, and $18.6 \%$ are in technical positions.

\section{Emerging Employment Commons in Bizkaia: A Cooperative Ecosystem Linked to a Singular Territory}

Bizkaia is one of the three historical territories of the Basque Country, region placed in the North of Spain, and one of the seventeen Spanish autonomous regions. The Basque Country was first recognized as an autonomous region in 1936 by Spain's then democratic government, and in that year the first Basque regional government was established. The Spanish Civil War (1936-1939) and the dictatorship headed by General Francisco Franco which ascended in its wake, however, soon made it impossible for the Basque Government to fully manage the region's affairs. With Franco's death and the end of the military dictatorship in 1975, the political landscape shifted dramatically within both Spain and the Basque Country. By 1977 the Basque territories started to organize themselves, and a Basque executive authority was created soon thereafter. The Spanish Constitution was ratified by popular referendum in 1978, and a year later, the Basque population voted massively in favor of the Law of Autonomy that the major political parties had been previously agreed upon.

The Spanish Constitution of 1978 and the Statute of Autonomy of the Basque Country of 1979 gives the Basque Country and its three historical territories (Bizkaia, Gipuzkoa and Araba/Álava) a high degree of self-government. Under this statute, the region and the three territories were granted a broad range of powers in all social, industrial, economic, educational, and cultural areas, including its own Treasury Department, which exists alongside that of the central government. Thus, the three Basque territories have the authority to enact legislation covering virtually the entire taxation system, including tax assessment and collection. The special status of the three historical territories of the Basque autonomous region constitutes a confederal model within the region, as each territory has a legislative assembly and wide-ranging powers.

The economic situation of the Basque Country in 1980 was itself very fragile, as it was in many other regions in Europe. The earlier oil crises had disrupted the economy, generating high inflation and increasing unemployment. At the same time, terrorism, institutional reform, and social unrest created additional economic uncertainties and negatively affected investment.

Yet, a few decades later, the Basque autonomy is firmly secured, and the Basque population enjoy a high standard of living within Spain and Europe, with positive prospects for its continued social and economic evolution (Velasco 2000). Nowadays, the historical territory of Bizkaia population is estimated at 1,142,583 people, its GDP in $36,181,562$ million euros (Eustat-Instituto Vasco de Estadística 2020) and the Bizkaia unemployment rate stands at $11.4 \%$. The Provincial Council of Bizkaia is the main public institution of the territory, and develops its actions in cooperation with Biscayan town councils, the Basque Government and the Spanish Government.

Molded by its history and current social, economic, and political characteristics, it is in this territory where Bizkaia's embryonic Employment Common is located. It is an ecosystem of diverse social, private, and public agents where, through progressively increased reciprocity and the establishment of cooperative dynamics, they acquire this singular character recognizing the paradigm of the commons. Beyond the inevitable competitive logic between entities that operate in the same economic sectors, Bizkaia's employment ecosystem has shown itself to be a prolific space for collaboration. Examples such as (1) industrial sector clustering processes in collaboration with public and social 
institutions, as well as universities, which started in the 1990s and was later consolidated (Elola et al. 2012; Ahedo 2006); (2) the implementation of programs such as the 3Rs (Requalification, Reinsertion, and Relocation) in cooperation between Bizkaia Provincial Council itself and local development and employment centers, universities, businesses, and other local social entities with hiring commitments; (3) the Gazte On program, a comprehensive program that combines assessment, training, support, and work experience so that socially disadvantaged young people can enter into stable employment, cooperating with vocational training centers and social entities; (4) the Laborlan employment-training program with job placement in collaboration with clusters, professional associations, and sectoral business associations; and (5) the Sarekin network, which collaborates with the entrepreneurship ecosystem to support entrepreneurial projects, present an ecosystem that is prepared for and open to cooperation. As presented in the following conclusions, an employment commons has allowed for a collective assessment to be carried out on COVID-19's impact, as well as a shared design of socio-economic measures in response. These processes appear to show an increased resilience and adaptability in the Bizkaia territory and employment ecosystem in the face of future shocks.

As with all other regions of the world, in this context, the COVID-19 crisis impacts Bizkaia in the form of a "landscape shock" (Geels and Schot 2007) meaning a shock to the social, labor, economic, technological, and ecological environment that will mark a turning point on multiple fronts. In fact, the arrival of the COVID-19 pandemic impacts heavily in Spain and the Basque Autonomous region and its three historic territories in March 2020. Spain's economy contracted heavily by $11 \%$, and the Basque GDP by $10 \%$ during that year. The unemployment rate-one of the highest in the European Union-soars and public institutions have to adopt a wide range of heterodox initiatives in order to defend the economy and the labor market. Between March and June 2020, the Provincial Council of Bizkaia adopts and deploys a special employment plan with measures to support workers and enterprises. The Provincial Council carries out this plan after doing an ecosystemic diagnosis of the employment situation in the territory through an inclusive and participatory process.

This "landscape shock" of dramatic consequences also opens up a window of opportunity to adapt institutions and policies so that they can respond not only to the present pandemic, but also to other challenges on the horizon, such as the climate emergency (Briggs et al. 2015; Steffen et al. 2018; Ripple et al. 2019; Atutxa et al. 2020), demographic ageing (Calvo-Sotomayor et al. 2019; Calvo-Sotomayor et al. 2020), the green transition (Atutxa Ordeñana et al. 2020), and the digital revolution (Verhoef et al. 2021; Hodson 2018; Arnaldi et al. 2010; Boas et al. 2005). The following results show the efforts made by Bizkaia Provincial Council to mitigate COVID-19's impact on employment through the use of the previously characterized governance and interpretation framework of the Commons.

\section{Results}

In the advancement of its configuration into an Employment Common, the employment ecosystem in Bizkaia shows a capacity for an overall evaluation regarding COVID-19's impact and the responses to mitigate its consequences. As another component of the ecosystem, Bizkaia Provincial Council plays a catalyzing and coordinating role in said actions. Once again, in their interaction with the other entities that make up the ecosystem, local public administrations show a singular competence when it comes to activating dynamics of convergence and cooperation in the Commons (Barbieri 2014; Subirats 2011).

This collaboration, catalyzed by the local public sphere at a time of urgency and confusion, has enabled an assessment of the impact and the definition of collective proposals. Collective knowledge has allowed for an aligned, shared reaction during the first months of the pandemic, which has resulted in the detection of impacts that would have otherwise remained invisible. Specifically, through the previously described qualitative and quantitative analyses, Bizkaia's own employment ecosystem identifies (1) the priority groups that must be protected first, (2) the harm done to various sectors of activity and 
their expected recovery, and (3) defines public economic policies to be implemented with the highest degree of versatility and speed possible. The following are the main results obtained from this extensive fieldwork.

\subsection{Priority Groups Based on COVID-19 Impact}

The ecosystemic analysis of COVID-19's impact provides highly relevant conclusions about the mutual recognition between agents that make up Bizkaia's embryonic Employment Common. Detaching themselves from the individual impact they experienced, the stakeholders demonstrate a significant ability to identify those they consider to have suffered the greatest impact. In fact, there is unanimity among the entities consulted when it comes to indicating that the most vulnerable groups must benefit from priority action. The entities are capable of thinking about diverse vulnerability from different perspectives, vulnerability that is rich in nuances, allowing for the conclusion that, indeed, the ecosystemic approach provides the assessment with greater sophistication and complexity to benefit the subsequent definition of policies and actions. The following (Table 1) presents a breakdown of the most vulnerable groups resulting from an analysis of the information provided by the ecosystem itself. With a focus on individuals that were already in a precarious employment situation before COVID-19's impact, Bizkaia's employment ecosystem adds certain cross-cutting conditions that result in the increased vulnerability of certain groups.

Table 1. Priority sub-groups depending on their vulnerability to COVID-19's impact (compilation based on the information collected from our fieldwork).

\begin{tabular}{ll}
\hline $\begin{array}{l}\text { Sub-Groups Including Individuals Found to Be in Precarious } \\
\text { Employment Situations Beforehand }\end{array}$ & Cross-Cutting Conditions That Intensify Vulnerability \\
\hline Individuals with limited term and part-time contracts & Women, particularly domestic workers and caretakers \\
\hline $\begin{array}{l}\text { Long-term unemployed individuals in a situation of chronic } \\
\text { unemployment }\end{array}$ & $\begin{array}{l}\text { Individuals over the age of 45, as well as those nearing } \\
\text { retirement }\end{array}$ \\
\hline Individuals with limited term and part-time contracts & $\begin{array}{l}\text { Younger individuals with little work experience or recent } \\
\text { graduates. }\end{array}$ \\
\hline Individuals with low qualifications & Single-parent families \\
\hline $\begin{array}{l}\text { The self-employed and employees of previously weakened } \\
\text { micro-SMEs }\end{array}$ & Migrants \\
\hline Individuals that have recently started new business projects & Dependants \\
\hline
\end{tabular}

As such, we find ourselves with a Bizkaia employment ecosystem that largely prioritizes individuals who have seen their situation deteriorate severely due to the COVID-19 crisis' impact, and other groups that were already in highly-vulnerable situations that saw their conditions gravely worsened (TS_18) ${ }^{1}$. The following is part of an express response from one of the entities surveyed, which reflects the previously presented idea.

On whom to focus actions and who should be prioritized depends on whether we are looking to make a quick impact that allows for rapid recovery, or if we want to help those who are going to have it the hardest and leave the rest to the market's pace (CLU_5).

Likewise, they consider that target groups for programs previously aimed at the most vulnerable could be a good starting point for the optimal targeting of Bizkaia Provincial Council's aid measures and employment stimulus. In any case, they point out that data analysis is a fundamental aspect for guiding measures.

Acting with prudence and contrasted data, referring to groups that have actually lost their jobs. This will require obtaining reliable data from those that have it, the Basque Employment Service-Lanbide (AP_9).

As a reflection of the entire ecosystem, there are also voices that opt for uniform intervention regardless of the impacted groups' initial conditions. However, these are a 
minority in Bizkaia's employment ecosystem. There are only three entities that believe that this homogenized focus would be preferable (DS_1), leaving the decision to opt for aid in the hands of the applicant entities (ASO_2).

Lastly, using the same logic of scarce resource prioritization and allocation for the most vulnerable, Bizkaia's employment ecosystem explicitly demands greater cooperation and coordination between the various levels of the public administrations (provincial, regional, national, and supranational). As such, the entities believe that Bizkaia Provincial Council's actions in the area of employment must be targeted and complement all other aid and measures implemented by other public administrations on other levels. While this is beyond the scope of this research, the ecosystem's request points to the necessary scale that must be produced in the commons for an efficient and comprehensive response to problems that have risen to a global scale, and that cannot be resolved solely through local action due to their magnitude (Atutxa Ordeñana et al. 2020; Harvey 2012; Mignolo 2002; Klein 2001).

\subsection{Sectors of Activity That Are Currently the Most Affected}

As a complement to quantitative analyses from official secondary sources, this investigation shows the Bizkaia employment ecosystem's profound knowledge on COVID-19's impact. This knowledge is pegged to reality and, to a certain degree, is only spread to those given access if the approach is systemic. Each unit that makes up this ecosystem completes and complements the vision of the other units, and Bizkaia Provincial Council activates mechanisms so that this information can be brought together and collected. In fact, in some cases this is very highly valuable information that official statistics institutions are unable to collect and offer systematically. A clear example of this is caretaker and domestic work essentially carried out by women that is often relegated to the informal economy. Referred to as "domestic work", these economic activities are critical to sustaining our economies and societies yet fly under conventional radars and spring up through dialogue and knowledge that is collectively produced in the ecosystem. If Bizkaia's employment ecosystem had not shared this information, the impact on domestic workers could possibly have been under-represented.

Nonetheless, the surveys carried out reflect a certain consensus among the entities when it comes to identifying the most hard-hit economic activities. Of the entities consulted, $89.5 \%$ (77 out of 86 ) believe that hospitality is the economic activity most adversely affected by COVID-19 (Figure 3). Commercial retail ( $84.9 \%$ ) and tourism $(80.2 \%)$ are also deeplyaffected activities according to the territory's public, private, and social entities. Thanks to the systemic approach, domestic workers come in fifth place. Of the entities consulted, $48.8 \%$ believe that this is actually one of the most affected activities. 


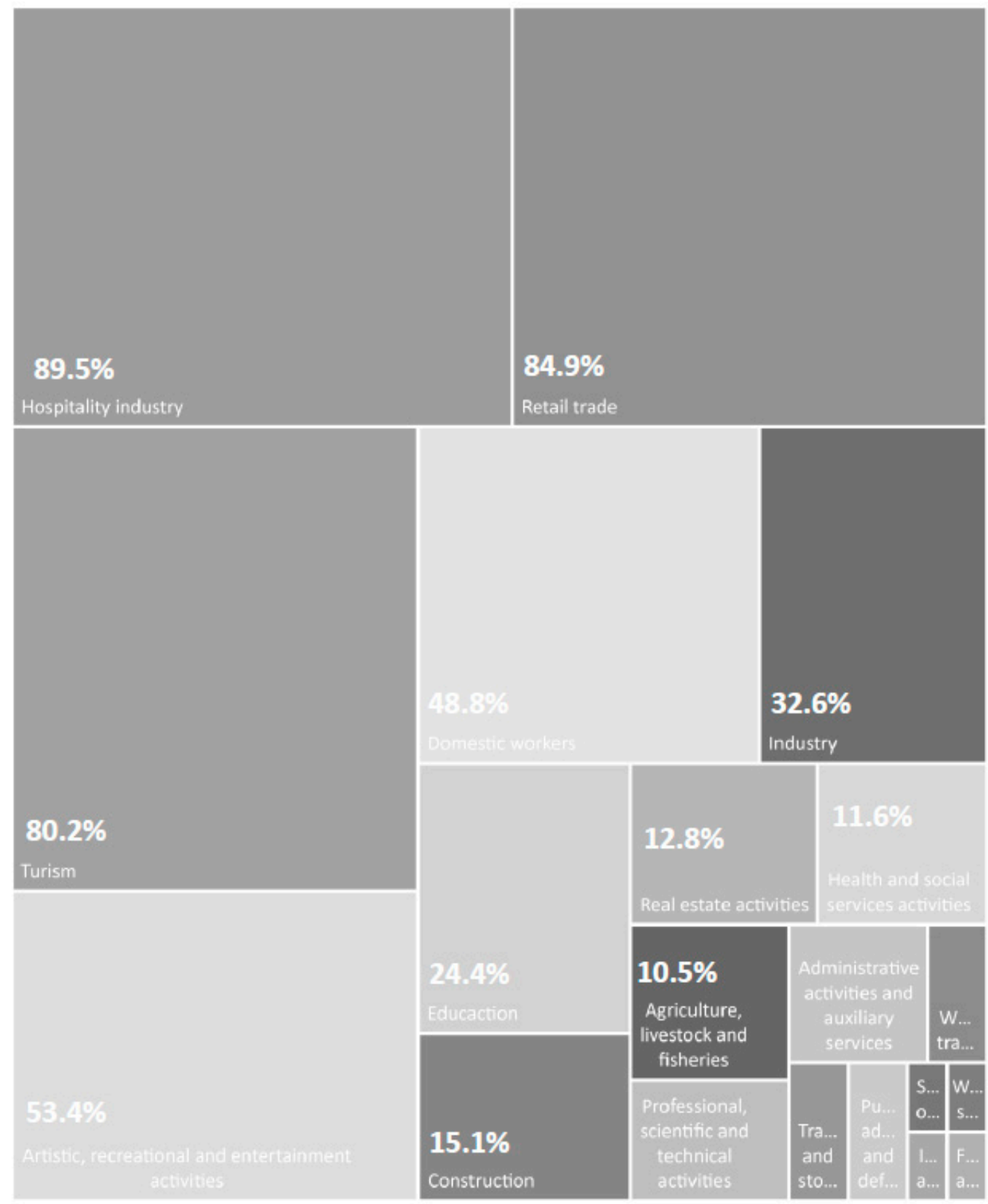

Figure 3. Sectors of activity that are currently the most affected according to the entities' selection in terms of the total responses received.

\subsection{Sectors of Activity That Are Expected to Recover First}

When asked about the activities that will recover from the impact first, this is when the ecosystem and its collective knowledge present greater division. There is no economic activity that receives more than $52 \%$ agreement (Figure 4). We believe that this behavior could be due to the high level of uncertainty and dynamism caused by COVID-19. In fact, during the initial impact, all of the entities that provide forecasts faced serious difficulties. Many of them even missed the mark on the pandemic's expected evolution. In profoundly uncertain scenarios such as the one caused by COVID-19's impact, and regardless of its dispersal, the ecosystem's knowledge that is closely connected to reality is again useful to provide further information for decision-making that is as well founded as possible. 


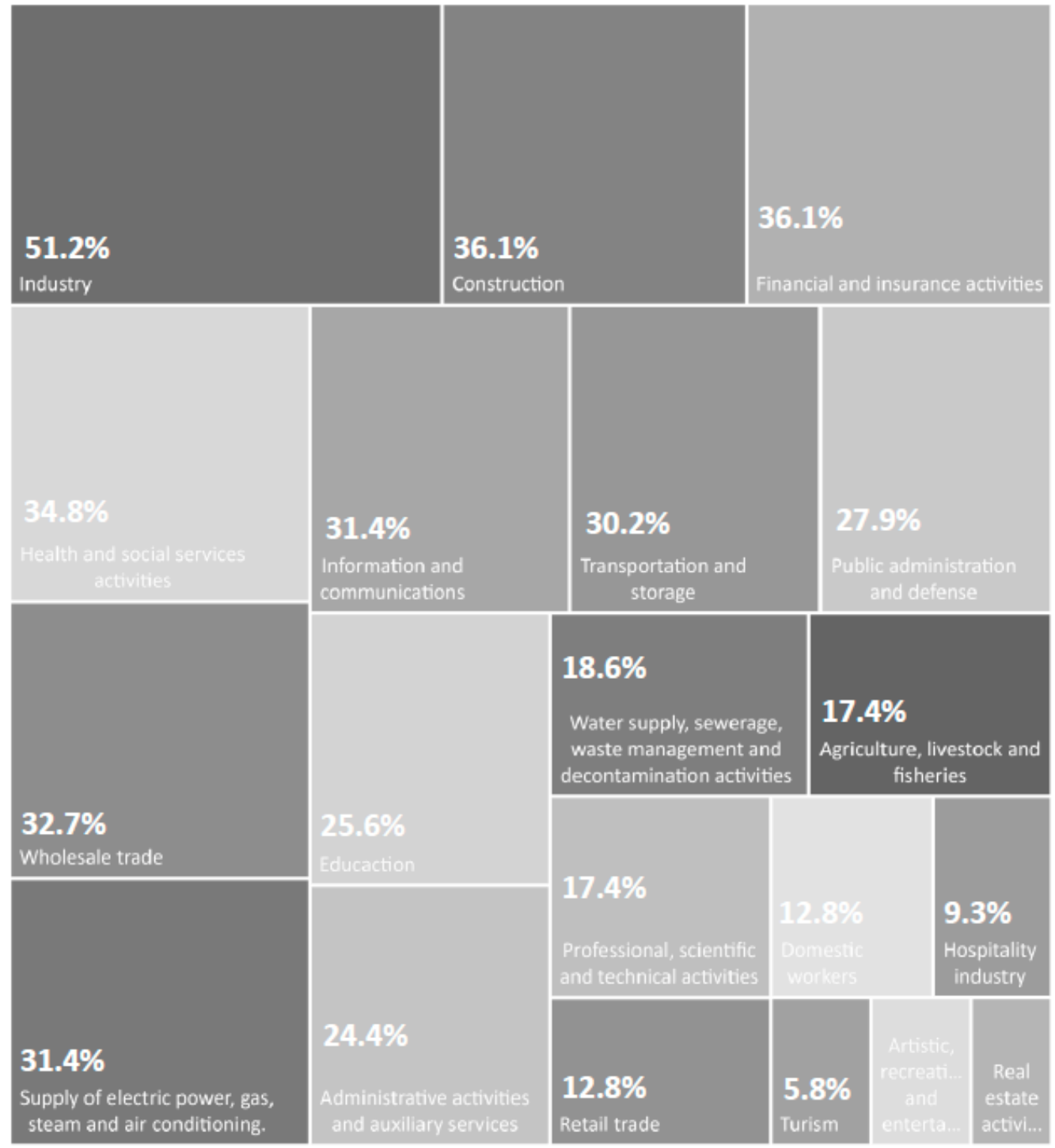

Figure 4. Sectors of activity that are expected to recover first according to the entities' selection in terms of the total responses received.

Nonetheless, $51.2 \%$ of the entities consulted believe that industry will recover from the impact first. Construction, as well as financial and insurance activities, received $36.1 \%$. It is of particular interest to contrast this with the fact that only $12.8 \%$ believe that domestic activities will recover first. Once again, we can see that the ecosystem recognizes the most vulnerable groups and activities that are not represented in conventional secondary sources of information, which are unable to understand the informal economy systematically. In terms of hospitality and tourism, this last data point drops to $9.3 \%$ and $5.8 \%$.

4.4. Comparison between Sectors Considered to Be the Most Adversely Affected in Terms of Those Expected to Recover First

Once again, through the knowledge of the entities that make up Bizkaia's employment ecosystem, it is capable of identifying the activities and sectors that will have the greatest difficulty overcoming the crisis caused by COVID-19. As can be seen in Figure 5, according to the entities consulted, the sectors least affected by the pandemic are also those that have the greatest expected recovery ability and speed. In this case, this conclusion coincides with the information analyzed through secondary sources. Only one singularity arose, which is noted for further study in future research. Based on the information obtained from Bizkaia's employment ecosystem, only the area of education shows a qualitatively 
similar impact and recovery level ( $24 \%$ and $26 \%$, respectively). As a possible hypothesis to be contrasted with future work, this could be due to the coexistence of private and public training centers, the latter of which could be perceived as more robust when it comes to cushioning and surviving the impact.

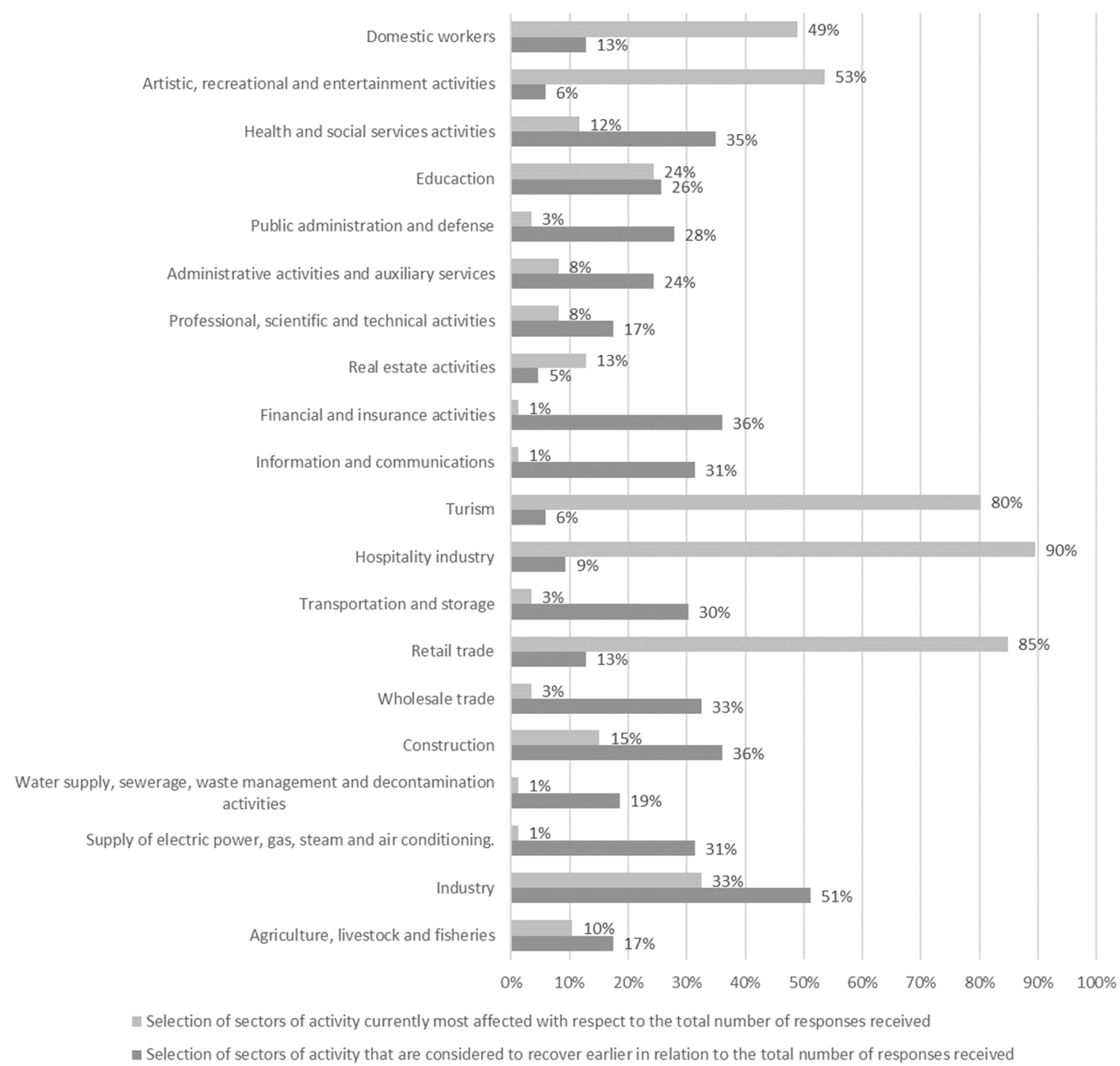

Figure 5. Comparison between sectors considered to be the most adversely affected in terms of those expected to recover first.

Nonetheless, this investigation's fieldwork was carried out in close collaboration with the employment ecosystem, which served to equip the macroeconomic analyses carried out by official organizations with greater consistency and guarantee that there were no blind spots for subsequent employment policy definition.

Addressing the profile of individuals and entities that generate and maintain employment in Bizkaia, there is a broad consensus that SMEs (and micro-SMEs in particular), self-employed individuals, and small entrepreneurs with fewer financial resources, are the segments that are being hardest hit by the crisis' impact, and are also those that are anticipated to have the most difficult recovery. In addition to productive economic activity's conventional sectors, they mention the crisis' impact on reproductive activities that sustain domestic workers in particular. They point to the importance of remembering that this is a precarious and highly vulnerable sector (Instituto de la Mujer y para la Igualdad de Oportunidades 2020) that, in addition to being an activity with a high level of exposure to infection, is relegated to the informal economy as mentioned previously. Once again, we 
see an employment ecosystem that is concerned and aware of the need to protect the most vulnerable segments, in this case business sectors.

The most hard-hit, those that are very small limited companies with one or two freelancers or personnel they are responsible for and investments in real estate, materials... As of now there is no aid for these types of companies (ASE_2).

They recognize that there is support and aid for larger-sized entities, for which reason they believe that Bizkaia Provincial Council should focus on those that are left most exposed. On the basis of complementarity, focus is placed on the most vulnerable individuals and businesses.

Likewise, medium-sized companies are also recognized as a segment to protect against the impact of COVID-19. As indicated by the ecosystem itself, their difficulties in terms of downsizing or "cutting the fat" when faced with sudden moments of crisis like this one, and increased demands for liquidity, complicate their activity's continuity (CLU_1). For that reason, they point to the road map for diverse economic activity support and intervention that is found in the De-escalation Plan. The uncertainty and great variability of the crisis force Bizkaia's employment ecosystem to take on a dynamic and adaptable approach to the circumstances.

Lastly, from a globalized economy perspective, Bizkaia's employment ecosystem also recognizes that the most hard-hit businesses are those exposed to international markets with large value chains (e.g., aerospace, automotive, etc.), as well as those that depend on international mobility and leisure (e.g., tourism) (CLU_5). In contrast, all businesses and sectors that depend on goods that are difficult to replace (e.g., electricity, water, food, etc.), and those that are not affected by international traffic due to their own intangibility (e.g., financial products, communications, etc.) will be those that suffer less through the crisis and will recover the quickest (CLU_5, EM_10).

\subsection{Looking for the Common Good: Prioritizing the Most Vulnerable, a Policy Proposal from and to the Ecosystem}

The following are the employment policies that were defined during the first months of the shock (April-July 2020) based on the previously completed collective assessment. As Bizkaia's employment ecosystem indicated, these are policies with marked dynamism that were able to be adapted to the pandemic's fluctuations. It is important to note that these are profoundly disruptive and innovative policies, yet they are also deeply collective and consistent with reality in Bizkaia. The process's innovation is produced through ecosystemic definition and assessment. This process made it possible for a robust approach to address the needs of the territory derived from COVID-19's impact, which collectively consolidated the prioritizing of the most vulnerable segments. It is a potential Employment Common that is not willing to leave anyone behind, nor leave anyone out. Specifically, the measures proposed by the entities consulted for the employment segment are concentrated around five major categories:

1. Maintaining employment: on the basis of how close the impact was, Bizkaia's employment ecosystem deemed it a priority to implement economic measures aimed at sustaining Bizkaia's workers' labor conditions. To do this, they proposed a diverse set of mechanisms that could contribute to this goal.

They indicated that any economic measure that could enable companies to keep their workers on until normal activity resumed was vital for the survival of the largest possible swath of the ecosystem. Through knowledge drawn closest to the impact withstood, the entities consulted indicated that purchasing power, with particular attention paid to the most vulnerable groups (AP_20), would allow for the reactivation of all other activities in the short term (AP_3). Among other assistance, they proposed implementing specific aid to maintain contracts, support the self-employed, and/or temporarily cover a portion of Social Security contributions, etc.

In terms of the impact on activities geared towards the ecosystem's essential sustainment, also of particular interest are mentions of implementing measures aimed 
at promoting reconciliation between reproductive and productive work, as well as caretaker and professional activities. In these measures, the gender dimension is fundamental. Also, in the words of the Instituto de la Mujer y para la Igualdad de Oportunidades $(2020$, p. 6) "the traditional role of caretakers being assigned to women grants them a degree of presence when it comes to responding to the illness, which must be taken into account when addressing the crisis. Ignoring gender's impact on the social and economic consequences will worsen inequality". In other words, women are on the front line of the caretaker response. According to the Labor Force Survey (LFS), 66\% of healthcare personnel are women. Within the ecosystemic dynamic, underlying care and women's highly relevant role when it comes to mitigating the pandemic's impact are noted as a necessary line of future research that directly results from this study.

2. Encouraging and stimulating employment: in addition to previously existing ecosystem support, the consulted entities also believed that gradually implementing economic measures aimed at encouraging hiring unemployed individuals and boosting employment was a determining factor (AP_2, CON_1, AP_22): (1) Both those that were found to be in said situation before, and (2) those that fell into this situation due to the impact of the crisis. Both are priority groups. The former to avoid intensifying their prior situation of vulnerability (AP_20) and the latter to attempt to solve their situation before it became chronic (CLU_5). As such, Bizkaia's employment ecosystem recognized that when faced with an impact like that of COVID-19, opting for a defensive position was not sufficient, and adopting a proactive attitude for its empowerment and future sustainability was also essential.

Flexibility and increased aid for hiring through mechanisms like contracting bonuses are considered to be useful mechanics for this objective. In the entities' own words, this would promote measures that encourage hiring personnel (AP_1, EM_3). Facilitating the hiring of personnel necessary to relaunch affected activities (AP_9). Specifically, taking aim at SMEs and the self-employed through hiring aid, even if work is temporary or part-time (TS_17). Adapting pre-existing programs such as Lanberri to the current circumstances is also considered to be a possibility for evaluation in order to offer targeted responses for hiring individuals from vulnerable groups (TS_9).

Likewise, they consider the creation of a transitional subsidized employment space involving all agents as a possible measure (EM_9). They see the proposal to create a common, shared space as a way of advancing towards greater cooperation and tangible relations between the agents that make up the ecosystem: this is one way of moving towards the commoning of Bizkaia's employment ecosystem through the paradigm used in this article.

3. Support before and during employment: the entities consulted once again show their intent to protect the most vulnerable groups in particular. As such, they indicate that the ecosystem on the whole would become more robust if (1) comprehensive employment plans were implemented to provide job training, orientation, and support opportunities (TS_3); and (2) plans were implemented that included telephone and telematic support, orientation, and assistance services so that vulnerable and excluded individuals can return to "normality" along with their personalized inclusion plans (TS_1, EM_6). In both cases, they agree on the importance of defining these plans in agreement and direct, constant contact with all entities that make up the ecosystem (AP_11, TS_12). Facilitating access for individuals in search of work, or improving their current conditions at companies in order to produce "training experience" and "contact" networks (EM_7). Once again, the importance of a territory like Bizkaia having an ecosystem capable of establishing reticular dynamics of mutual recognition and collaboration emerges. This is an approach to the logic of the Employment Commons in which Bizkaia Provincial Council, as the ecosystem's main public component, could play a convergent, catalyzing role. 
4. Challenge-oriented employment training: Bizkaia's employment ecosystem highlights the importance of implementing programs that combine training and subsequent hiring. This would be a conventional proposal if not for its particular focus on the specific orientation that these training programs must include. From the perspective of the Commons, they indicate that training programs being focused on solving the real challenges faced is a determining factor for the ecosystem to be truly capable of better responding to possible future shocks. To do this, they point to the necessity of said programs' own design having greater interaction with and incorporation of the ecosystem's real needs (TS_12). It is the opinion of some entities that the continued assessment of the conditions being produced in the ecosystem, and subsequent continued re-design of re-qualification programs, is one of the cornerstones to achieving greater collective resilience (EM_11). In this work, and due to their intricate knowledge of the day-to-day reality experienced by the entities that make up the ecosystem, they highlight the relevant role that local programs aimed at strategic and driving sectors could play (TS_4).

Lastly, with training, they also make special mention of the protection and particular support that the most vulnerable segments must receive. As the most fragile link on which the entire ecosystem's well-being depends, they consider it entirely necessary to (1) guarantee family income so they can address and recuperate their work training plans, and (2) support work-life balance so that women are at the same starting point when it comes to being involved in work training processes (TS_12).

5. Other favorable measures for the ecosystem on the whole, and advancement towards creating an Employment Common:

In addition to measures specific to the area of employment described above, when it comes to creating a more robust and resilient ecosystem that is attentive to diversity, meaning an Employment Common, the entities point to other complementary measures that would be useful to move forward with in the following areas (Table 2).

Table 2. Other favorable measures to advance towards an Employment Common.

\begin{tabular}{l} 
(Compilation Based on the Information Collected from Our Fieldwork) \\
\hline Creating support teams for emotional and psychological recovery. \\
\hline Promoting spaces of reflection and debate to think about new economic development models. \\
A tractor project made up of local benchmark spaces for open innovation where organizations, \\
individuals, institutions, and communities can collaborate on the development of innovative \\
product approaches, service provision, business models, and consumption that contributes to a \\
social and circular economy (CLU_4). \\
As an example, they suggest the suitability of a project connected to responsible consumption and \\
food waste recovery that is capable of demonstrating that this transition towards a more \\
sustainable and social economy can be done, that it is efficient, and that it is viable. A project of \\
this type could become a beacon for the appearance of new projects and initiatives (CLU_4). \\
\hline Measures aimed at encouraging employment in sustainable sectors: biodiversity, clean energy, \\
caregiving, etc. \\
\hline Promoting retail and local service and product consumption. \\
\hline Implementing a universal basic income. \\
\hline Ensuring basic needs (housing and food) for the entire population through meal allowances, rent \\
payments, and deferred mortgage payments.
\end{tabular}

\section{Discussion and Conclusions}

This research demonstrates that Bizkaia's employment ecosystem meets the conditions necessary for it to be able to advance towards the future creation of an Employment Common. Among others, (1) focus and priority for the most vulnerable segments, (2) recognition of the local scale as a priority area of action as it is so closely linked to the territory, (3) active 
participation to carry out a collective policy definition and assessment, and (4) the entities' own ecosystemic self-perception all lead to the conclusion that this is fertile ground for creating not just a common governance of employment, but also a further search for the common good.

Beyond the institutional characteristics expected of a Common initiative (Wieviorka 2020), the results described above allow us to conclude that the Employment ecosystem in Bizkaia advances in the collectivization and democratization of the modes of governance by placing the different social agents and the people who make them up at the center of participation and decision-making. A conception of the Commons that, overcoming its capacity to complement the public-state and the private-market spheres, offers new opportunities to critically review the traditional representation of the economy and opens the possibility to new forms of collective and inclusive action.

Likewise, as this paper has highlighted, we can predict that moving forward in this direction could result in the creation of an employment ecosystem that is more resilient and adaptable to new shocks, which is identified in the introduction as a living machine (Morin 2008). However, even if this ecosystem evolves towards greater resilience and adaptation, it will always be exposed to external shocks and disturbances.

The extensive fieldwork carried out allows us to conclude that an ecosystemic approach through the compilation of the voices of the entities and the collaboration between them provides a differential value to respond to external shocks such as that of COVID-19. The visibility and attention to groups that are usually underrepresented in the formal economy and its measurement indicators is one of the most valuable contributions. According to Bizkaia's own employment ecosystem, the informal (and also formal) jobs performed mainly by women, which are central to sustaining our economies and societies, have suffered a profound impact and should therefore be the object of special attention. A conclusion that, although it could have been intuited by a local public administration, acquires a central position from the moment it is recognized by the entities themselves as an essential aspect for the survival of the ecosystem.

Likewise, the policies defined in Bizkaia to mitigate and overcome the impact of COVID-19 are highly innovative. Not so much because of the areas on which they aim to have an impact (employment, employability, training) and the mechanisms established (hiring aid, training programs, etc.), but because of the dynamism incorporated in their initial definition and subsequent readaptations. The information gathered from the employment ecosystem of Bizkaia and its transformation into a collective knowledge has had an impact on the processes of definition and execution of employment policies of the County Council of Bizkaia. Thus, we are facing an innovation in the processes of public administration that has resulted in a greater dynamism, absolutely necessary in the face of a shock that generates so much uncertainty. Perhaps a change that is not so visible but decisive to provide the ecosystem with greater agility, adaptability, and resilience.

In fact, the emerging Employment Commons of Bizkaia understands that the COVID-19 pandemic is a dynamic phenomenon that affects sectors of activity unevenly. They point out that the first to close (e.g., hospitality and leisure) will be the last to open and that those labor-intensive and more physically interactive are hit harder (e.g., retail, care, etc.). The collective recognition of these factors is what has led the employment ecosystem of Bizkaia to take care of the most vulnerable from a dynamic approach in the definition and implementation of measures. From the consulted entities perspective, in the face of a gradual crisis resolution, the protection of the most disadvantaged and adaptability take on a central position.

The research has also made it possible to place at the heart of the debate the necessary complementarity that must exist at the different scales. The employment ecosystem of Bizkaia is fully aware of the deep internal capacities it has and that it is necessary to activate in order to respond to an impact. However, it is also aware that these collective capacities are not sufficient to achieve the best possible response. Faced with problems that have acquired a global scale and that are capable of producing such profound socioeconomic 
impacts, the entities consulted demand greater communication and coordination not only among themselves. The fieldwork carried out highlights the need for coordination and complementarity with other local, state, and European administrations in order to avoid overlapping and duplication. A coordination that also has to be capillarized by districts and municipalities of Bizkaia. They point out that it is very important to agree on the active employment policies, to make them compatible by districts, fairly creating district reference centers. In short, to create a network that allows common and greater objectives in an orchestrated way (AP_19). We thus note that the emerging Employment Common of Bizkaia detects complementarity on both micro and macro scales as an essential line of work.

One limitation of the study is that the survey conducted by the Provincial Council of Bizkaia took place in April 2020, and the conclusions are drawn from data relating to 3 months of pandemic. In any case, it is important to note that since that date both economic activity and employment have behaved positively, gradually returning to pre-pandemic employment levels.

Finally, it is worth noting that Bizkaia's employment ecosystem is also able to look to the long term. In addition to the pressing short-term measures, it states that the necessary structural reforms must be undertaken to anticipate and respond to similar challenges in the future. Just one example of this is the creation of spaces for reflection and debate to think about new models of economic development or measures to promote employment in sustainable sectors. The magnitude and ferocity of the pandemic called for rapid and forceful action in the short and long term. Measures that, while resolving the urgency, are also capable of structurally transforming our socioeconomic systems.

Author Contributions: Conceptualization, E.A., I.C.-S. and T.L.; methodology, E.A. and I.C.-S.; validation, E.A., I.C.-S. and T.L.; formal analysis, E.A. and I.C.-S.; investigation, E.A., I.C.-S. and T.L.; resources, E.A., I.C.-S. and T.L.; data curation, E.A. and I.C.-S.; writing-original draft preparation, E.A. and I.C.-S.; writing-review and editing, E.A., I.C.-S. and T.L.; visualization, E.A. and I.C.-S.; supervision, E.A.; project administration, E.A., I.C.-S. and T.L. All authors have read and agreed to the published version of the manuscript.

Funding: This research received no external funding.

Institutional Review Board Statement: Not applicable.

Informed Consent Statement: Not applicable.

Data Availability Statement: 3rd Party Data. Restrictions apply to the availability of these data. Data was obtained from the Provincial Council of Bizkaia and are available from the authors with the permission of the Provincial Council of Bizkaia.

Acknowledgments: We thank the Provincial Council of Bizkaia who provided data and insight for the research. We also appreciate the insight and comments from the Employment Common agents of Bizkaia, and the feedback from the anonymous reviewers on early drafts of this paper.

Conflicts of Interest: The authors declare no conflict of interest.

\section{Appendix A. List of Surveyed Entities}

The following is a list of companies and entities in Bizkaia that participated in the survey processes in entity codification order:

\begin{tabular}{cccc}
\hline Code & Sector & Entity & Position \\
\hline AP_1 & Public Administration_City Council & Ayuntamiento De Balmaseda & Manager \\
AP_10 & Public Administration_City Council & Urduñederra (Ayto Orduña) & Technitian \\
AP_11 & Public Administration_City Council & Bermeoko Udala & Directorate \\
AP_12 & Public Administration_Develpoment & Forlan, Agencia Desarrollo Local & Manager \\
AP_13 & Agency & De Muskiz & Manager \\
AP_14 & Public Administration_City Council & Ayto Karrantza & Manager \\
AP_15 & Public Administration_City Council & Ayuntamiento Sestao & Manager \\
\hline
\end{tabular}




\begin{tabular}{|c|c|c|c|}
\hline Code & Sector & Entity & Position \\
\hline AP_16 & $\begin{array}{c}\text { Public Administration_Employment } \\
\text { Center }\end{array}$ & Meatzaldeko Behargintza, S.L. & Manager \\
\hline $\mathrm{AP} \_17$ & $\begin{array}{c}\text { Public Administration_Develpoment } \\
\text { Agency }\end{array}$ & Egaz Txorierri & Directorate \\
\hline AP_18 & Public Administration_City Council & Ayuntamiento De Arrigorriaga & Technitian \\
\hline $\mathrm{AP}_{-} 19$ & Public Administration_City Council & Ayuntamiento De Zalla & Manager \\
\hline AP_2 & $\begin{array}{c}\text { Publica Administration_Municipal } \\
\text { Associtation }\end{array}$ & $\begin{array}{c}\text { Mancomunidad De La Merindad } \\
\text { De Durango }\end{array}$ & Directorate \\
\hline AP_20 & Rural Development Agency & Adr Gorbeialde & Directorate \\
\hline AP_21 & Rural Development Agency & ADR Enkarterrialde & Technitian \\
\hline $\mathrm{AP} \_22$ & Rural Development Agency & $\begin{array}{l}\text { Urremendi Landa Garapen } \\
\text { Elkartea }\end{array}$ & Manager \\
\hline AP_3 & Public Administration_City Council & Ayuntamiento De Erandio & Technitian \\
\hline $\mathrm{AP}_{-4}$ & Public Administration_City Council & Ayuntamiento De Erandio & Technitian \\
\hline AP_5 & $\begin{array}{c}\text { Public Administration_Develpoment } \\
\text { Agency }\end{array}$ & Leartibai Garapen Agentzia & Technitian \\
\hline AP_6 & $\begin{array}{c}\text { Public Administration_Employment } \\
\text { Center }\end{array}$ & Behargintza Leioa & Directorate \\
\hline $\mathrm{AP}_{-} 7$ & Public Administration_City Council & $\begin{array}{l}\text { Ayuntamiento Valle De } \\
\text { Trápaga-Trapagaran }\end{array}$ & Technitian \\
\hline AP_8 & Public Administration_City Council & Ayuntamiento De Ermua & Technitian \\
\hline AP_9 & Public Administration_City Council & Ayuntamiento De Portugalete & Directorate \\
\hline ASE_1 & Association_Business & Nekatur & Directorate \\
\hline ASE_2 & Association_Business & $\begin{array}{c}\text { AKTIBA, Asociación De Empresas } \\
\text { De Turismo Activo De Euskadi }\end{array}$ & Directorate \\
\hline ASE_3 & Association_Business & Aed & Technitian \\
\hline ASE_4 & Association_Business & Asle & Technitian \\
\hline ASE_5 & Association_Business & $\begin{array}{c}\text { Asociación De Hostelería De } \\
\text { Bizkaia }\end{array}$ & Manager \\
\hline ASE_6 & Association_Business & Gremio De Pasteleria De Bizkaia & Directorate \\
\hline ASE_7 & Association_Business & $\begin{array}{c}\text { Asociacion Vizcaina De } \\
\text { Excavadores }\end{array}$ & Manager \\
\hline ASE_8 & Association_Business & $\begin{array}{c}\text { Fundación Laboral De La } \\
\text { Construcción País Vasco }\end{array}$ & Manager \\
\hline ASO_1 & Association_Oficial College & $\begin{array}{l}\text { Colegio Oficial De Químicos E } \\
\text { Ingenieros Químicos }\end{array}$ & Manager \\
\hline ASO_2 & Association_public private & Enkartur & Manager \\
\hline CF_1 & $\begin{array}{l}\text { Learning Center_Vocational } \\
\text { Trainning }\end{array}$ & C.F. Somorrostro & Manager \\
\hline CF_2 & $\begin{array}{c}\text { Learning Center_Vocational } \\
\text { Trainning }\end{array}$ & Ikaslan & Manager \\
\hline CF_3 & $\begin{array}{c}\text { Learning Center_Vocational } \\
\text { Trainning }\end{array}$ & Centro Formativo Otxarkoaga & Manager \\
\hline CF_4 & $\begin{array}{c}\text { Learning Center_Vocational } \\
\text { Trainning }\end{array}$ & Centro San Viator & Manager \\
\hline CF_5 & $\begin{array}{l}\text { Learning Center_Vocational } \\
\text { Trainning }\end{array}$ & Hetel & Directorate \\
\hline CLU_1 & Cluster_Business & Asociación Cluster De Energía & Directorate \\
\hline CLU_2 & Cluster_Business & $\begin{array}{c}\text { Asociación De Fundidores Del País } \\
\text { Vasco Y Navarra }\end{array}$ & Technitian \\
\hline CLU_3 & Cluster_Business & Gaia & Directorate \\
\hline CLU_4 & Cluster_Business & Aclima & Directorate \\
\hline CLU_5 & Cluster_Business & $\begin{array}{c}\text { ACICAE-Cluster Automoción De } \\
\text { Euskadi }\end{array}$ & Directorate \\
\hline CON_1 & Business Confederation & Cebek & Directorate \\
\hline CU_1 & Learning Center_University & Upv/Ehu & Technitian \\
\hline CU_2 & Learning Center_University & Universidad De Deusto & Directorate \\
\hline DS_1 & Unknown & Unknown & Unknown \\
\hline DS_2 & Unknown & Unknown & Unknown \\
\hline DS_3 & Unknown & Unknown & Unknown \\
\hline DS_4 & Unknown & Unknown & Unknown \\
\hline DS_5 & Unknown & Unknown & Unknown \\
\hline DS_6 & Unknown & Unknown & Unknown \\
\hline DS_7 & Unknown & Unknown & Unknown \\
\hline DS_8 & Unknown & Unknown & Technitian \\
\hline DS_9 & Unknown & Unknown & Unknown \\
\hline EM_1 & Business & HETEL (Hetelenpresa) & Manager \\
\hline EM_10 & Business & Velatia SL & Directorate \\
\hline EM_11 & Business & Petronor & Directorate \\
\hline EM_2 & Business & Fundación Lantegi Batuak & Technitian \\
\hline EM_3 & Business & Talleres Gallarreta Lantegiak, S.L. & Manager \\
\hline EM_4 & Business & Maier S.Coop. & Manager \\
\hline EM_5 & Business & Bidagin, Sl & Directorate \\
\hline EM_6 & Business & Taller Usoa Lantegia.S.A.U & Manager \\
\hline EM_7 & Business & Peñascal Kooperatiba & Manager \\
\hline EM_8 & Business & Galletas Artiach & Manager \\
\hline EM_9 & Business & Petronor Sa & Technitian \\
\hline SD_1 & Trade union & Ccoo Empleo & Manager \\
\hline
\end{tabular}




\begin{tabular}{cccc}
\hline Code & Sector & Entity & Position \\
\hline TS_1 & Social sector & Gaztaroa Sartu Kooperatiba & Directorate \\
TS_10 & Social sector & Elkartea & Directorate \\
TS_11 & Social sector & Fundacion Ede Fundazioa & Manager \\
TS_12 & Social sector & Asoc. ETORKINEKIN BAT, Por La & Manager \\
TS_13 & Inclusión Social Elkartea & Manager \\
TS_14 & Social sector & Asociacion Sortarazi & Manager \\
TS_15 & Social sector & Red Social Koopera & Directorate \\
TS_16 & Social sector & Apnabi Empleo Autismo Bizkaia & Cnknown \\
TS_17 & Social sector & Cáritas Bizkaia & Manager \\
TS_18 & Social sector & Fundacion Claret Sozial Fondoa & Directorate \\
TS_19 & Social sector & Fundación Integrando & Unknown \\
TS_2 & Social sector & Caritas Diocesana De Bilbao & Directorate \\
TS_20 & Social sector & Zabaltzen Sartu Kooop Elk & Manager \\
TS_3 & Social sector & Ftsi & Manager \\
TS_4 & Social sector & Ede Fundazioa & Directorate \\
TS_5 & Social sector & Asociacion TENDEL & Directorate \\
TS_6 & Social sector & Nevipen Ijito Elkartea & Manager \\
TS_7 & Social sector & Elkarbanatuz & Technitian \\
TS_8 & Social sector & Asociación Berriztu & Manager \\
TS_9 & Social sector & Fundación Etorkintza & Manager \\
\hline
\end{tabular}

\section{Note}

1 Each party surveyed was assigned a code (e.g., TS_18). Whenever a code of this type appears in the text, it indicates the ideas and assertions of a specific entity (the complete list of codes and entities can be consulted in Appendix A).

\section{References}

Ahedo, Manu. 2006. Business systems and cluster policies in the Basque Country and Catalonia (1990-2004). European Urban and Regional Studies 13: 25-39.

Arnaldi, Simone, Francesca Boscolo, and Julia Stamm. 2010. Living the digital revolution-Explorations into the futures of the European Society. European Review for Medical and Pharmacological Sciences 18: 399-416. [CrossRef]

Atutxa, Ekhi, Imanol Zubero, and Iñigo Calvo-Sotomayor. 2020. Scalability of low carbon energy communities in spain: An empiric approach from the renewed commons paradigm. Energies 13: 5054. [CrossRef]

Atutxa Ordeñana, Ekhi, Imanol Zubero Beascoechea, and Iñigo Calvo-Sotomayor. 2020. El paradigma de lo común y la gestión de la energía en España: Oportunidades para la convergencia entre diferentes. Scripta Nova Revista Electrónica de Geografía y Ciencias Sociales 24. [CrossRef]

Barbieri, Nicolás. 2014. Unas políticas de lo cultural. Kult-ur 1: 101-19. [CrossRef]

Beck, Ulrich. 2006. Cosmopolitan Vision. Cambridge: Polity Press.

Boas, Taylor, Thad Dunning, and Jennifer Bussell. 2005. Will the digital revolution revolutionize development? Drawing together the debate. Studies in Comparative International Development 40: 95-110. [CrossRef]

Bogdan, Robert, and Sari K. Biklen. 2006. Qualitative Research in Education: An Introduction to Theory and Methods. Boston: Allyn \& Bacon.

Bollier, David, and Silke Helfrich, eds. 2014. The Wealth of the Commons: A World beyond Market and State. Amherst: Levellers Press.

Boutiller, Sophie, and Beatriz Castilla-Ramos. 2012. La precarización del mercado de trabajo: Análisis desde Europa y América Latina y el Caribe. Papeles Poblac 18: 239-70.

Briggs, Stephen, Charles F. Kennel, and David G. Victor. 2015. Planetary vital signs. Nature Climate Change 5: 969-70. [CrossRef]

Browne, Kath. 2005. Snowball sampling: Using social networks to research non-heterosexual women. International Journal of Social Research Methodology: Theory and Practice 8: 47-60. [CrossRef]

Bryman, Alan, and Emma Bell. 2007. Business Research Methods. Oxford: Oxford University Press.

Byrne, John, and Leigh Glover. 2002. A common future or towards a future commons: Globalization and sustainable development since UNCED. International Review for Environmental Strategies 3: 5-25.

Calle, Ángel, Rubén Suriñach, and Conchi Piñeiro. 2017. Comunes y economías para la sostenibilidad de la vida. In Rebeldías en común: Sobre comunales, nuevos comunes y economías cooperativas. Madrid: Ecologistas en acción.

Calvo-Sotomayor, Iñigo, Ekhi Atutxa, and Ricardo Aguado. 2020. Who is afraid of population aging? Myths, challenges and an open question from the civil economy perspective. International Journal of Environmental Research and Public Health 17: 5277. [CrossRef]

Calvo-Sotomayor, Iñigo, Jon Paul Laka, and Ricardo Aguado. 2019. Workforce ageing and labour productivity in Europe. Sustainability 11: 5851. [CrossRef]

Carter, Nancy, Denise Bryant-Lukosius, Alba Dicenso, Jennifer Blythe, and Alan J. Neville. 2014. The use of triangulation in qualitative research. Oncology Nursing Forum 41: 545-47. [CrossRef] [PubMed]

Dahlberg, Lincoln, and Eugenia Siapera. 2007. Radical Democracy and the Internet. London: Palgrave Macmillan. 
Elola, Aitziber, Jesús M. Valdaliso, Santiago M. López, and Mari Jose Aranguren. 2012. Cluster Life Cycles, Path Dependency and Regional Economic Development: Insights from a Meta-Study on Basque Clusters. European Planning Studies 20: 257-79. [CrossRef]

Eustat-Instituto Vasco de Estadística. 2020. Anuario estadístico vasco. Vitoria-Gasteiz: Gobierno Vasco.

Geels, Frank W., and Johan Schot. 2007. Typology of sociotechnical transition pathways. Research Policy 36: 399-417. [CrossRef]

Goldin, Ian, and Mike Mariathasan. 2014. The Butterfly Defect. Princeton: Princeton University Press.

Goldin, Ian, and Robert Muggah. 2020. The Conversation. Available online: https://theconversation.com/the-world-before-thiscoronavirus-and-after-cannot-be-the-same-134905 (accessed on 20 July 2021).

Guest, Greg, Arwen Bunce, and Laura Johnson. 2006. How Many Interviews Are Enough? An Experiment with Data Saturation and Variability. Field Methods 18: 59-82. [CrossRef]

Harvey, David. 2012. Rebel Cities: From the Right to the City to the Urban Revolution. London: Verso.

Hodson, Richard. 2018. Digital Revolution. Nature 563: S131. [CrossRef] [PubMed]

Instituto de la Mujer y para la Igualdad de Oportunidades. 2020. La perspectiva de género, esencial en la respuesta a la COVID-19. Madrid: Ministerio de Igualdad.

International Labour Office. 2011. Global Employment Trends 2011. Geneva: ILO.

Klein, Naomi. 2001. Reclaiming the Commons. New Left Review 9: 1-5.

Laclau, Ernesto, and Chantal Mouffe. 2014. Hegemony and Socialist Strategy: Towards a Radical Democratic Politics. London: Verso.

Lucarelli, Stefano, and Carlo Vercellone. 2014. The thesis of cognitive capitalism. New research perspectives. An introduction. Knowledge Cultures 1: 2-14.

Max-Neef, Manfred A. 1993. Desarrollo a escala humana: Conceptos, aplicaciones y algunas reflexiones. Barcelona: Icaria.

Mazzucato, Mariana. 2021. Mission Economy: A Moonshot Guide to Changing Capitalism. London: Penguin Books Ltd.

Mignolo, Walter. 2002. Historias Locales/Diseños Globales. Colonialidad, Conocimientos Subalternos y Pensamiento Fronterizo. Madrid: Akal. Morin, Edgar. 2008. On Complexity. Cresskill: Hampton Press.

Morse, Janice M. 1994. Designing funded qualitative research. In Handbook for Qualitative Research. Edited by N. K. Denzin and Y. S. Lincoln. Los Angeles: Sage, pp. 220-35.

OIT Americas. 2020. Tendencias mundiales del empleo juvenil 2020. Ginebra: OIT.

Ostrom, Elinor. 2015. Governing the Commons: The Evolution of Institutions for Collective Action. Cambridge: Cambridge University Press.

Patton, Michael Quinn. 2002. Qualitative Research and Evaluation Methods. Los Angeles: Sage.

Pickett, Kate, and Richard Wilkinson. 2010. The Spirit Level: Why Equality Is Better for Everyone. London: Penguin Books Ltd.

Ramonet, Ignacio. 2011. El nuevo 'sistema-mundo. Valencia: Le Monde diplomatique en español.

Rasul, Imran. 2020. The Economics of Viral Outbreaks. AEA Papers and Proceedings 110: 265-68. [CrossRef]

Riechman, Jorge. 2004. Gente que no quiere viajar a marte: Ensayo sobre ecología, ética y autolimitación. Madrid: Catarata.

Ripple, William J., Christopher Wolf, Thomas M. Newsome, Phoebe Barnard, and William R. Moomaw. 2019. World Scientists' Warning of a Climate Emergency to cite this version: World Scientists' Warning of a Climate Emergency. Bioscience 70: 8-12.

Rothbauer, P. M. 2008. Triangulation. In The SAGE Encyclopedia of Qualitative Research Methods. Edited by L. M. Given. Newbury Park: Sage.

Smith, Katherine F., Michael Goldberg, Samantha Rosenthal, Lynn Carlson, Jane Chen, Cici Chen, and Sohini Ramachandran. 2014. Global rise in human infectious disease outbreaks. Journal of the Royal Society Interface 11: 1-6. [CrossRef] [PubMed]

Steffen, Will, Johan Rockström, Katherine Richardson, Timothy M. Lenton, Carl Folke, Diana Liverman, Colin P. Summerhayes, Anthony D. Barnosky, Sarah E. Cornell, Michel Crucifix, and et al. 2018. Trajectories of the Earth System in the Anthropocene. Proceedings of the National Academy of Sciences of the United States of America 115: 8252-59. [CrossRef] [PubMed]

Subirats, Joan. 2011. Otra sociedad, ¿otra politica? De "no nos representan" a la democracia de lo común. Barcelona: Icaria.

Taleb, Nassim Nicholas. 2007. The Black Swan: The Impact of the Highly Improbable. New York: Random House.

Vázquez, Antonio. 2007. Desarrollo endógeno. Teorías y políticas de desarrollo territorial, Investigaciones Regionales. Journal of Regional Research 11: 183-201.

Velasco, Roberto. 2000. La descentralización de la política industrial española: 1980-2000. Econ Industries 335: 15-34.

Vercellone, Carlo, and Alfonso Giuliani. 2019. Common and commons in the contradictory dynamics between knowledge-based economy and cognitive capitalism. In Cognitive Capitalism, Welfare and Labour: The Commonfare Hypothesis. London: Routledge.

Verhoef, Peter C., Thijs L. J. Broekhuizen, Yakov Bart, Abhi Bhattacharya, John Qi Dong, Nicolai Fabian, and Michael Haenlein. 2021. Digital transformation: A multidisciplinary reflection and research agenda. Journal of Business Research 122: 889-901. [CrossRef]

Wieviorka, Michel. 2020. Sis reflexions sobre la pandèmia. Idees: Revista de temes contemporanis 51: 13.

Wucker, Michele. 2016. The Gray Rhino: How to Recognize and Act on the Obvious Dangers We Ignore. New York: Macmillan. 